\title{
Literary and Visual Forms of a Domestic Devotion: The Rosary in Renaissance Italy
}

\author{
Erminia Ardissino
}

The Rosary is one of the most widely practiced forms of domestic devotion in modern Italy. Literature and cinema document the deep penetration of this form of prayer into the culture and lives of Catholic Italians. The Rosary, however, is not rooted in the ancient past, as some other prayers are; the practice dates to the late fifteenth century, and became widely diffused in the sixteenth and seventeenth centuries.

The period of the spread of the Rosary was one of dramatic change in Italy and the rest of Europe, characterised by the development of printing, the increasing prominence of vernacular languages, the discovery of previously unknown places and cultures, the defining of new intellectual professions and political theories of government, the growing prominence of the laity in intellectual and social life, new religious doctrines, and the formation of European confessionalism. In some ways many of these elements, which characterized the early modern era, played a role in the development and spread of the devotional practice under consideration. I would particularly underline the importance of printing, the role of the laity, the Reformation, and open confrontation between different peoples, religions and cultures (with the consequence that many commercial routes and forms of labour and production were altered dramatically), as fundamental elements that contributed to the spread of the Rosary.

In this paper, I will first consider how the popularity of the Rosary in early modern religious practice can be viewed as a response to the needs of the time. Secondly, I will investigate two major aspects of its diffusion in Renaissance Italy: in iconography and poetry. Publications on the Rosary were often accompanied by rich and detailed illustrations, effective meditational aids, which made the books masterpieces of the new art of printing and suitable for numerous uses. In addition, poetry on the Rosary was a genre of popular literature that used literary Italian to represent a form of devotion that employed the vernacular alongside Latin. Rosary verse moreover generated the opportunity for the translation of common Latin prayers into vernacular poetic forms.

(C) ERMINIA ARDISSINO, 2019 | DOI:10.1163/9789004375871_016

This is an open access chapter distributed under the terms of the prevailing CC-BY-NC-ND License at the time of publication. 


\section{On the Development of Rosary Devotion}

Repetitive forms of prayer, of which the Rosary is one, existed in medieval monastic practice. The Rosary was first developed by Dominic of Prussia and Adolf of Essen in a monastic setting at the beginning of the fifteenth century. These two Carthusian monks of a charterhouse at Trier, working from the basis of pre-existing devotional exercises, promoted a Marian devotion composed of prayers and narrative meditations on Christ's life. ${ }^{1}$ But it was a Dominican, Alanus de Rupe, in the second half of the century, who gave the Rosary the momentum that spread it across Europe, and above all amongst the laity.

Born in French Britanny in 1428, Alanus entered the Dominican order early in life, studied theology in Paris, and from 1459 until his death in 1475 was a professor in various cities, such as Paris, Lille, Douay, Ghent and Rostock. He thus travelled widely in Northern Europe, and besides teaching he also preached, successfully disseminating the practice of the Rosary as he travelled. His main legacies were the definition of the prayer in the form in which it is still used today, and the foundation of Confraternities 'of the Psalter of the Virgin Mary', which were intended to spread the Rosary among the laity. At his death he left only manuscripts, but his works soon benefitted from recent advances in printing. His Apologeticus, sive tractatus responsorius de Psalterio Beatae Virginis Mariae had already been printed in Lübeck by around 1480, and was reprinted several times in various other cities in the following decade, spreading his ideas on the Rosary throughout Europe. ${ }^{2}$ In 1500 the Apologeticus was also published in Bologna, in a miscellany compiled by Stefano of Piopera. ${ }^{3}$

Alanus dedicatedhis theologicalworks, the PrincipiumsuperIII Sententiarum and the Expositio regulae Sancti Augustini, to the Rosary, as a form of devotion

1 The role of the Carthusian monks in the invention of the Rosary has been underlined by Winston-Allen A., Stories of the Rose. The Making of the Rosary in the Middle Ages (University Park, PA: 1997) 13-30; see also Duval A., "Rosaire", in De Guibert J. - Viller M. - Cavallera F. (eds.), Dictionnaire de spiritualité (Paris: 1988) 937-980. On repetitive medieval prayers see Spinelli G., "Alle origini tardomedievali del Rosario. Devozione mariana di Benedettini, Cistercensi e Certosini", in Barile R. (ed.), Il rosario tra devozione e riflessione, Sacra Doctrina 54, 4 (2009) 171-183. On the parallels between the Rosary and the Muslim crown see Ambrosio, A.F., "Tra glorificazione e divinazione. Il tesbîh nell'Islam", in Barile, Il rosario tra devozione e riflessione $25^{8-274}$.

2 Lübeck, Printer of Fliscus (Lucas Brandis?): ca. 1480.

3 Stephanus de Piopera, Quodlibet de veritate fraternitatis Rosarii. Add: Alanus de Rupe, Compendium psalterii Trinitatis. Epilogus psalterii. De Psalterio B.M.V. exempla (Bologna, Johannes Antonius de Benedictis: 1500). 
to the Virgin Mary. ${ }^{4}$ In these works he tried to prove that both the Psalter of the Virgin and the first Confraternity 'of the Psalter of the Virgin Mary' were inspired by St. Dominic. In doing so, he implicitly claims the inventions for his own order, rather than the Carthusians. ${ }^{5}$ Alanus portrays St. Dominic as the principal promoter of the Virgin's psalter during his life, within his order, and in his time (anachronistically before the real development of the devotion).

It is evident that the speed with which the Rosary spread was due to the medium of print, which created a 'revolution', including in religious attitudes. Its diffusion was also helped by the new role played by laypeople in religious activities. Religious life in the fifteenth century was becoming less dependent on ecclesiastical decision-making, and the development of confraternities not only offered the laity a means of becoming more active in Church life, but also drove demand for new devotional practices that could be conducted without clerical leadership.

The Rosary met these needs well. In fact, after the first confraternity settled in Douay around 1470, others were soon constituted across Europe, in Cologne in 1475 and in other parts of Germany, as well as in France and Italy. The fact that the confraternities of the Rosary responded to the demands of a more secularised form of religiosity is shown by the suspicion that the Douay Confraternity aroused, with the local bishop requiring Alanus to explain its activity. ${ }^{6}$ Moreover, it is noteworthy that the first confraternities spread in areas that had previously engaged with the devotio moderna at the time of its decline. Evidently, these confraternities responded to the desire for greater spirituality expressed by the mainly lay followers of Geert Groote and Thomas à Kempis. The Virgin's psalter could be recited by laypeople, the destitute, or the illiterate; it did not require a special place of worship or clergy. It was not intended, however, to remove devotional life from under ecclesiastical control, but rather to offer members of the laity new possibilities for structuring their relationships with God. It combined meditative exercises with repetitive ones in order to satisfy the spiritual needs of a lay congregation. In fact the Rosary,

4 On this French Dominican friar see Meersseman G.G., "Alano de la Rupe e le origini della confraternita del Rosario", in Meersseman G.G. - Pacini G.P., Ordo fraternitatis. Confraternite e pietà dei laici nel Medioevo (Rome: 1977) 1044-1070; Quétif Jacques - Echard Jacques, Scriptores Ordinis Praedicatorum (Paris, apud Christophorum Ballard et Nicolaum Simart: 1719-1721) I, 849-852; Barile R., Il rosario, salterio della Vergine (Bologna: 1990); Roncelli A., "San Domenico e la nascita del Rosario nell'opera di Alano della Rupe", in Barile, Il Rosario tra devozione e riflessione 146-170. Alanus' preaching on the Rosary in Douay was transcribed and published under the title: L'ordonnance de la confraire du psautier de la glorieuse Vierge Marie (Paris, Michel Le Noir: probably in 1500).

5 These statements are found in chapter 8 of his Apologeticus.

6 Roncelli, "San Domenico e la nascita del Rosario" 153-155. 
unlike most private prayers, has particular characteristics that make it suitable for popular practice. Like most prayers, it can be recited individually, but it is mainly designed to be spoken in a group context. Although choral recitation was not recommended in Italy until 1601, the Rosary had always had a communal character, and it even promoted the constitution of compagnie or confraternities. ${ }^{7}$ Each member of a confraternity of the Rosary was supposed to recite a Rosary every day, in order to benefit from spiritual rewards from the Virgin Mary; failure to do so led to being deprived of these spiritual benefits.

The Rosary has a ritual aspect that individual prayers lack, and it is highly structured. It entails the recitation of 150 Ave Marias, clustered in groups of ten, preceded by a Pater noster and the proposition of a 'mystery' upon which to meditate. This number of 150 Ave Marias seems to be designed to correspond to the 150 psalms in the Davidic psalter, which is why the Rosary is also known as the 'Virgin's psalter'. It does not consist only of repetitive prayers, however, but also entails meditations. Indeed, the Rosary created by Dominic of Prussia was a kind of meditation on the life of Christ and Mary. In his Liber experientiarum he 'explicitly claimed to be the first to have composed a series of fifty points on the life of Christ that were to be meditated on while recit-

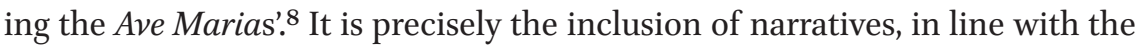
popular model of the Meditationes Vitae Christi, that characterises this type of devotion. In the modern Rosary, each decade of Ave Marias is preceded by meditation on one of the fifteen mysteries of salvation, that is to say an event of the incarnation in which the Virgin Mary was involved.

This form of devotion therefore combines ritual and personal meditation, orality and contemplation, repetitiveness and interior reflection, privacy and companionship, and provokes the imagination, bodily actions, wonder and compassion. Importantly, it can be recited at home without any special materials, as a corona (or set of rosary beads) is not essential, even if it quickly became a focal object of the devotional practice. As can already be seen in Alanus's Apologia, the corona was said to bring the protection of the Virgin to those who carried it, and it became the distinctive emblem of orders devoted to the Virgin Mary, who replaced the numeralia or signacula they used to count their prayers or Pater nosters with the corona organised in decades. ${ }^{9}$ The sacred

7 On early use of choral recitations, see Rosa M., "Pietà mariana e devozione del rosario nell'Italia del Cinque e Seicento", in Rosa M., Religione e società nel Mezzogiorno tra Cinque e Seicento (Bari: 1976) 117-143. As the Rosary is constituted of recitations added to meditations, it can be recited easily by multiple voices.

8 Winston-Allen, Story of the Rose 17.

9 Cecchin S.M., "Le corone dei sette gaudi e dei sette dolori: altre forme di preghiera del rosario", in Barile, Il Rosario tra devozione e riflessione 184-205: 192. 
nature of the corona is clearly shown by the fact that it became a prized object carried by pilgrims, and in many Italian regions it accompanies the corpse on its final pilgrimage after death.

The form of devotional Rosary practice initiated by the Dominicans, which became the most common, was not the only one: there were others, all based on the recitation of the Ave Maria and Pater noster, but distinguished by the fact that they were focused on different subjects for meditation. The Franciscan order developed its own form of corona, based on seven (rather than fifteen) meditations, which corresponded to the seven joys of the Virgin Mary's life. A work entitled Corona Beatae Mariae Virginis was even attributed to St. Bonaventure, and this devotion spread in Italy mainly in the midsixteenth century. ${ }^{10}$ Partly thanks to the work of Perbaltus of Temeswar in his Stellarium coronae benedictae Virginis Mariae in laudem eius (1506), and to John of Capestrano, who recommended recitation of the Rosary in a letter to a colleague in Nuremberg, it swiftly became popular in Germany too. It soon spread in Spain as well, thanks to the work of Ignacio of Mendoza, Los gozos de Nuestra Senora, and in France, thanks to the Tractatulus de tribus coronis Virginis Mariae by Gilbert Nicolas. ${ }^{11}$ This corona, known as the Franciscan corona, had indulgences conferred upon it by Pope Leo X in 1513 .

In a similar fashion, the Servite order developed the Rosary of the Seven Sorrows of the Virgin in the seventeenth century, also dedicated to contemplation of the mysteries of Christ's incarnation, but stressing devotion to the Addolorata. Arcangelo Ballottino's Fonte salutifera di Giesù ornata di considerationi, meditationi e soliloquii divoti et affettuosi (1608) specifically exhorted the lay members of his order (the Servite Third Order) to be attentive to the mysteries of Mary's sorrows. Ballottino's work received approval from Pope Paul v in 1607. Already in the constitutiones of this order the recitation of this corona was considered an acceptable replacement for the officium for the illiterate. ${ }^{12}$

10 The work attributed to St. Bonaventure appears in his Opera omnia (Ad Claras Aquas: 1882-1902) VIII, 677-679. See Cecchin, "Le corone dei sette gaudi e dei sette dolori: altre forme di preghiera del rosario". Evidence for the diffusion of the Franciscan crown is from: Marco dal Monte Santa Maria (or da Montegallo), La corona de la Vergine Maria (Venice, Bernardinus Benallus: 1494); the first vernacular Ave Maria is recorded by the same author in Marco dal Monte Santa Maria, Tabula de la salute (Venice, Nicolaus Belaguer: 1496). See Marco da Montegallo (1425-1496). Il tempo, la vita, le opere. Atti del convegno di studi (Padua: 1999) 213-227.

11 See Cecchin, "Le corone dei sette gaudi e dei sette dolori: altre forme di preghiera del rosario" 200.

12 The Servite constitutions read: 'Laici vero et nescientes legere quotidie intersint missae, et coronati, ut vulgo dicitur, loco omnium horarum dicant, quo negotia domi forisque 
There was also another form of the Rosary made up of 63 Ave Marias, corresponding to the 63 years of Mary's life, according to one of the many versions of her life. This Rosary was first used in 1373 by Saint Brigitte, but this is the only recorded example of its use. ${ }^{13}$ The original Carthusian form, which combines each Ave Maria with Marian or Christological attributes, was also still employed.

Although this variety of forms could be found when the Rosary was first practiced, the Dominican style of prayer is the one that has survived to the present day, and was the only variety that interested poets and artists. As use of the Rosary first spread in Italy in the fifteenth century, the literary and artistic production that accompanied it was not decisive for its survival, but undoubtedly aided its diffusion. ${ }^{14}$ From the beginning, publications on the Rosary came accompanied by lavish xilographic illustrations. The most striking of these can be found in the edition of the Rosario della gloriosa Vergine Maria by Alberto da Castello from 1521 [Fig. 14.1], which contains a wealth of illustrations. This clearly shows that the Rosary was not just an oral recitation, but was also a contemplative prayer engaging the imagination, a combination later mirrored by the exercises of Ignatius of Loyola.

Alberto da Castello, born in the middle of the fifteenth century in Venice, joined the Dominican order around 1470 and wrote several devotional, liturgical, historical and canonical texts. In the Epistola prohemiale of his Rosario della gloriosa Vergine Maria he says that he wrote the meditations and organised the images 'acciò che gli idioti che non sanno legere habbino el modo de contemplare gli divini beneficii et de questa contemplatione ne habbino qualche frutto spirituale. ${ }^{15} \mathrm{He}$ states that he writes especially for the 'ignoranti, illetterati, idioti', and that a good Christian must hold the mysteries of the Rosary deep in his heart.

possint exercere commodus'. Quoted from Cecchin, "Le corone dei sette gaudi e dei sette dolori: altre forme di preghiera del rosario" 210.

13 Ibid., 195.

14 Winston-Allen's work is primarily devoted to the Rosary in German culture.

15 Alberto da Castello, Rosario della gloriosa Vergine Maria (Venice, Marchio Sessa et Piero di Rauani: 1522) fol. 6r. 'So that even the illiterate have a means to contemplate gifts from the divine and to receive spiritual fruits from such contemplation' (translations are mine). See Fattori D., "Frate Alberto da Castello, un domenicano in tipografia", La Bibliofilia 109 (2009) 144-167. 


\section{Rofario oellagliofa vigine 21 Daria:}

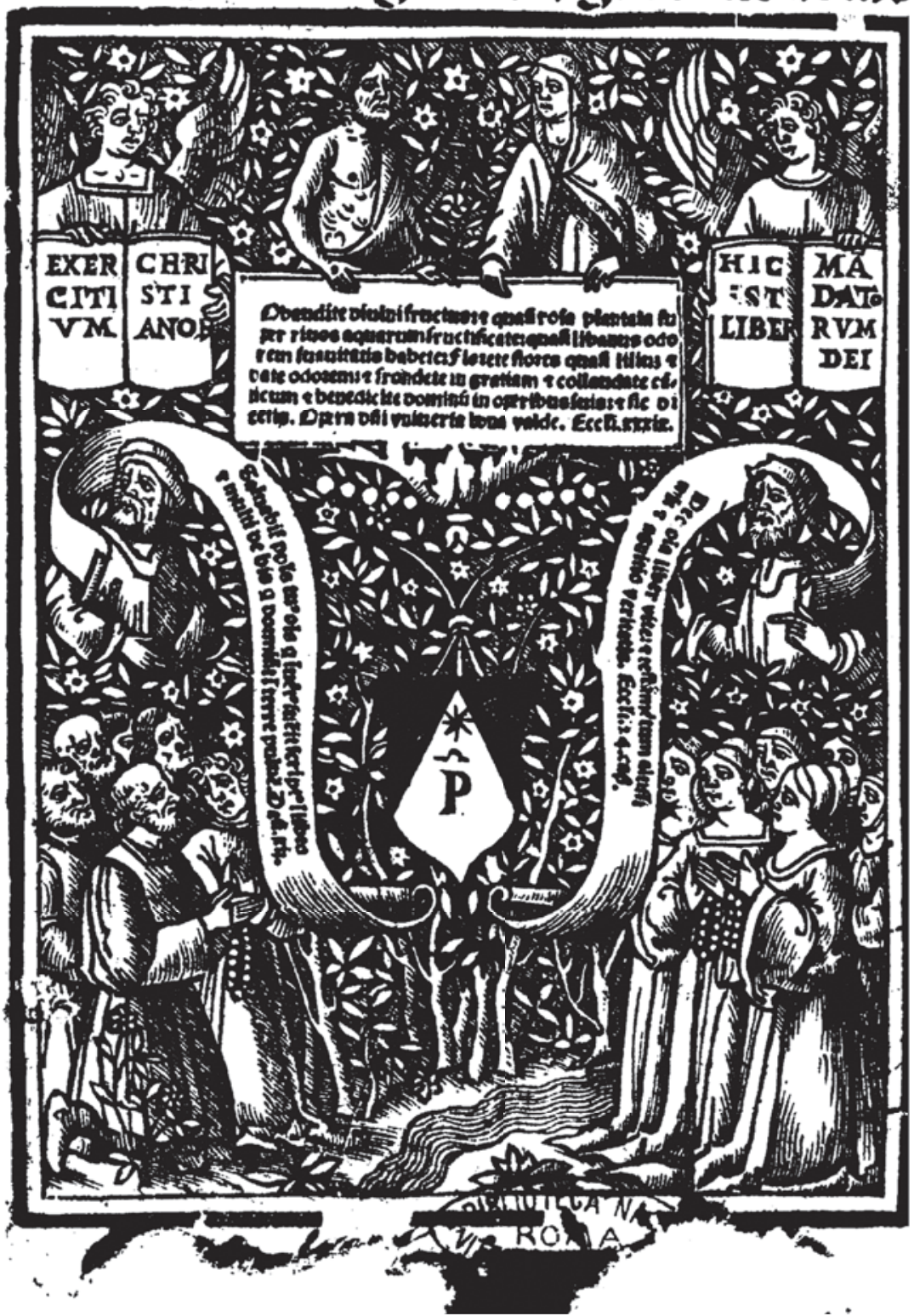

FIGURE 14.1 Alberto da Castello, Rosario della gloriosa Vergine Maria (Venice, s.n.: 1521), frontispiece. By kind permission of the Biblioteca Consorziale di Viterbo 
The first edition has an image for each Ave Maria as well as numerous images for each of the few Pater nosters, drawing attention to issues of particular note. In total there are more than 150 images, which appear on the back of a leaf (the left side of the book), while the meditation is printed on the facing recto (the right side of the book); the title is shared between two pages [Fig. 14.2 and Fig. 14.3]. Opening the book its subject matter is immediately evident in the title, in the image, and in the instruction for the recitation of the Ave Maria or Pater noster, the meditation which always begins with 'Contempla qui, anima fedele (or 'fedele e devota') come [...].'16 The mysteries are grouped into three sections: those of joy, those of passion, and those of glory. At the end there is an expositio of the main prayers involved, the Pater noster and the Ave Maria. The work concludes with a text explaining the miracles of the Rosary (Miracoli stupendifatti per virtu del rosario). The Rosario della gloriosa Vergine Maria is a complete guide to Rosary devotion and enjoyed great success, as shown by the approximately forty editions that were printed during the century.
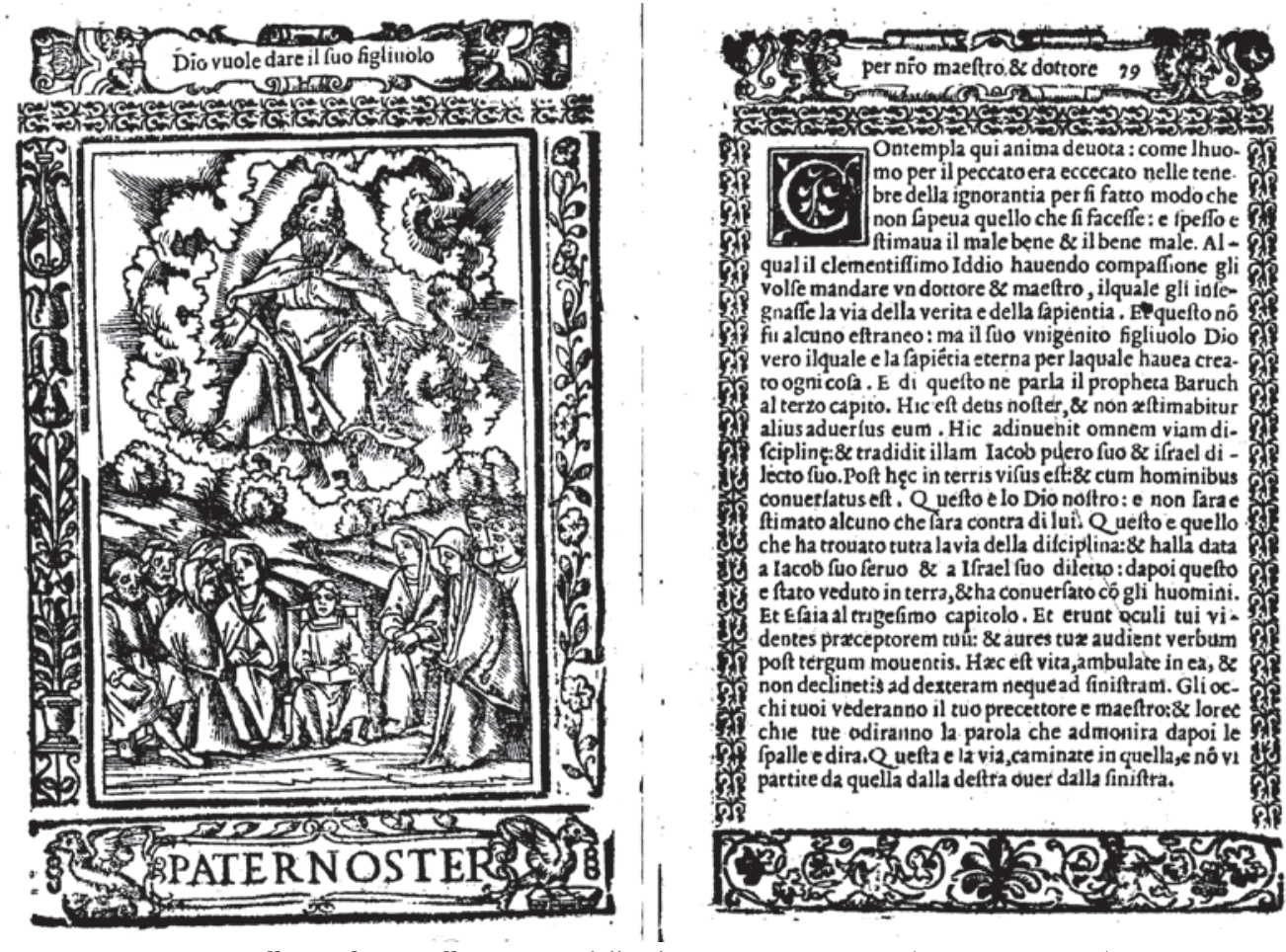

FIGURE 14.2 Alberto da Castello, Rosario della gloriosa Vergine Maria (Venice, s.n.: 1521)

fols. $78 \mathrm{v}-79$ r. By kind permission of the Biblioteca Consorziale di Viterbo

16 'Faithful (and devout) soul, contemplate here how [...]'. 

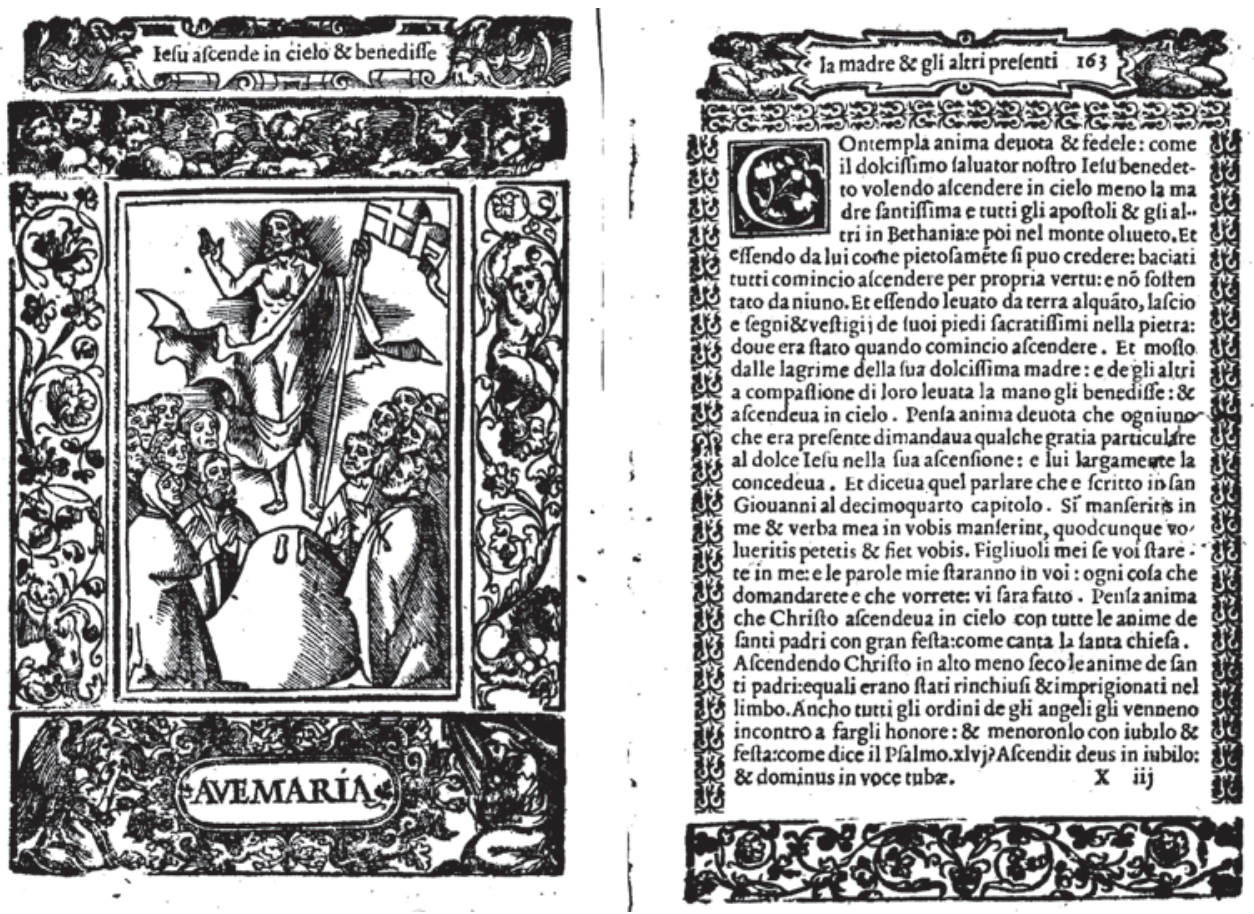

FIGURE 14.3 Alberto da Castello, Rosario della gloriosa Vergine Maria (Venice, s.n.: 1521), fols. 162r-163v. By kind permission of the Biblioteca Consorziale di Viterbo

The events of Christ's life are represented in words for those who can read and in images for the illiterate, which also served for visual meditation. ${ }^{17}$ Alberto recommends that every believer should teach the Rosary to his children:

et narrerete quelli alli vostri figlioli, insegnandoli a dire questo santo rosario. E quando sarete nelle case vostre sempre di questi pensareti. Et quando caminerete per el camino et viaggio, overo da uno luoco a laltro et quando anderete a dormire, et quando ve leverete dal dormire et reducetivi a memoria. Et ligareti quelli come un segno nelle man vostre per le filze de li pater nostri e ave marie, et li scrivereti sopra le porte et nelle porte delle case vostre mettando le figure di questo rosario sopra di esse e per le case vostre in continua memoria di essi. ${ }^{18}$

17 See for instance the many examples offered in Ardissino E.- Selmi E. (eds.), Visibile teologia. Il libro sacro figurato in Italia tra Cinquecento e Seicento (Rome: 2012).

18 Alberto da Castello, Rosario della gloriosa Vergine Maria, fol. 8r. 'You will tell the mysteries to your children, teaching them the holy Rosary. And when you are at home you should 
It is clear from these introductory lines that the Rosary was supposed to play a part in every moment of everyday domestic life, and to involve the whole family. It also shaped the relationship between parents and children, acting as a means for transmitting faith, religious practices, and beliefs. The role of the confraternity of the Rosary is also defined here, a confraternity which is supposed to be open to all: 'potenti e impotenti, nobili e ignobili, ricchi e poveri, huomini e donne' (those powerful and without power, noblemen and people without nobility, the rich and the poor, men and women). Membership is free, as stated in the first rule of the Cologne Confraternity, which is taken as a model here. ${ }^{19}$

The next successful Italian publication on the Rosary does not stress the domestic nature of the devotion as explicitly, although it was also produced by members of the Dominican order. The Rosario della sacratissima Vergine Maria, raccolto dall'opere del R.P.F. Luigi di Granata, published in 1573 , is in fact a collection of passages taken from the work of the eponymous and wellknown Spanish Dominican preacher, overseen by his brother (in the order) Andrea Gianetti of Salò. It was compiled in 1572, immediately after Pope Pius V proclaimed the $7^{\text {th }}$ of October as the feast of Our Lady of the Rosary in celebration of the victory of the Holy League at Lepanto (1571).

In his dedication, addressed to the Master of his order Serafino Cavalli, dated 25 March 1573 (the day of the Annunciation), Andrea Gianetti underlines the popularity of the Rosary:

Questa devotione di modo propagata e diffusa che non è parte del cristianesimo ove ella non sia, Iddio gratia, giunta, et con incredibile affetto e devotione abbracciata da ogni stato di persone. ${ }^{20}$

Giannetti states that, being unable to write meditations himself, he collected those by Luis de Granada and so made a mosaic of passages dealing with the

always think of them. And when you are walking and traveling from one place to another, and when you are going to sleep, and when you are getting up, you must remember them. And you will have them as a sign in your hand, attached to the string of the Pater nosters and the Ave Marias, and you will write them above your doors and on the doors of your houses, putting the image of the Rosary on the doors and on your houses as a perpetual reminder of them'.

19 Alberto da Castello, Rosario della gloriosa Vergine Maria, fols. $14 \mathrm{r}$ and $19 \mathrm{r}$.

20 Luis de Granada, Rosario della sacratissima Vergine Maria, raccolto dall'opere del RPF Luigi di Granata (Venice, Gioanne Varisco et Compagni: 1578). 'This worship has spread everywhere so that there is no place in the Christian world where it has not arrived, thanks to God, and where it has not been accepted with incredible affection and devotion by all kinds of people'. 
fifteen mysteries. After a number of chapters devoted to the earlier development of this form of devotion and to indulgences, the suggestions given for the recitation start by comparing the Rosary to daily food: as the body needs to be restored, so the soul needs spiritual food, such as that provided by the Rosary, which is a summary of Christ's life ('compendio della vita di Cristo'). ${ }^{21}$ It should be recitated 'nella hora del giorno più commoda e più atta', 'o nella chiesa commune o nella privata stanza' (at the most convenient and suitable hour of the day, in a church or in a private room). The most important aspect of the ritual is the attitude of the devotee: 'cuore humile, devoto, pieno d'amore e di timore, ridotto e raccolto davanti al cospetto di Dio.' ${ }^{22}$ This instruction clearly illustrates the potential difficulty of combining meditative and oral prayer, and so suggests starting with oral prayers, in order to stimulate the emotions, and then following with meditation, paying more attention to activity of the spirit:

Letto in qualche libro, o ridutto e rivocato alla memoria il passo o misterio che'l devoto ruminar e contemplar vuole nel cuor suo, deve imaginarsi che quel mistero si faccia inanzi a lui stesso, figurandolo così ne la sua imaginazione, poiché per simili cose si fu data da Dio questa potenza. ${ }^{23}$

The full-page illustrations by Adamo Scultori, slightly modified in subsequent editions, were therefore useful in supporting the workings of the imagination. In the 1578 edition they began with a symbolic image of the rose tree in which a crown unifies the five icons of the mysteries. In the center the Virgin Mary displays the Infant Jesus while in the other hand she holds a branch of the rose tree [Fig. 14.4]. ${ }^{24}$ The images for each decade of the Ave Maria are very beautiful, and were intended to help the imagination in the process of meditation. Granada-Gianetti's publication was highly successful, was reprinted several

\footnotetext{
21 Ibid., 3.

22 Ibid., 50 and 52. 'Humble and devout of heart, full of love and fear, absorbed in God's presence'.

23 Ibid., 50. 'After having read in some book, or recalled to memory the passage or mystery that the devotee should meditate and contemplate in his heart, he should imagine that the scene of that mystery is in front of him, picturing it in his imagination, since this power was given to us by God for similar things'. On this work's use of images see Arancibia P., "La funzione delle immagini nel Rosario della Sacratissima Vergine Maria Madre di Dio nostra signora", in Visibile teologia. Il libro sacro figurato tra Cinque e Seicento 179-190.

24 On the iconography of the Virgin of the tree see Gatti Perer M.L., "Per la definizione dell'iconografia della Vergine del Rosario", in Zardin D. (ed.), Carlo Borromeo e l'opera della 'Grande Riforma'. Cultura, religione, arte del governo nella Milano del pieno Cinquecento (Milan: 1997) 185-208.
} 


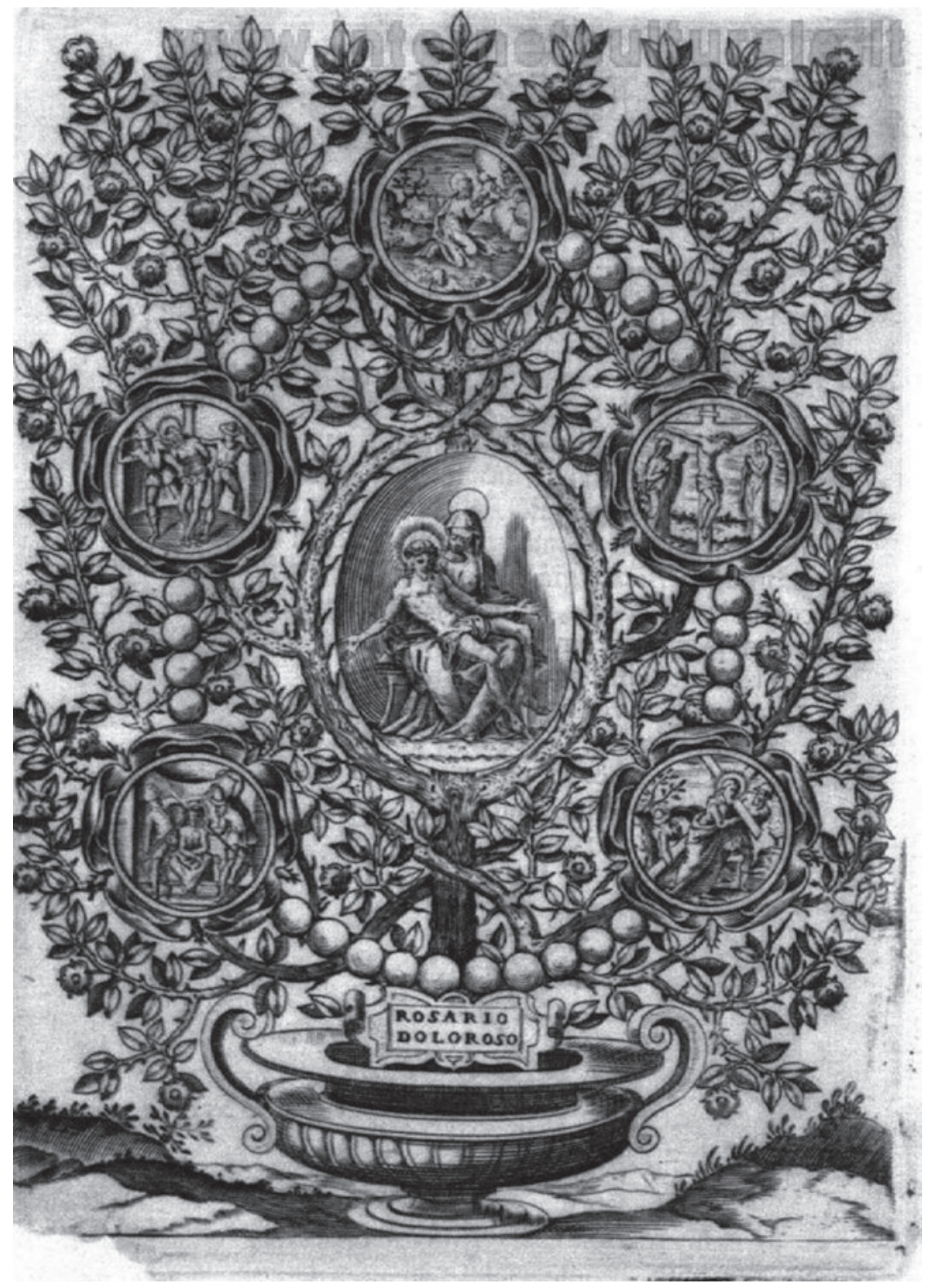

FIGURE 14.4 Luis de Granada, Rosario della sacratissima Vergine Maria, raccolto dall'opere del R.P.F. Luigi di Granata (Venice, Gioanne Varisco et Compagni: 1578) 56. By kind permission of the Biblioteca del Seminario del Polo Teologico Torinese, Turin 
times, and was subsequently enriched by the meditations of other Dominicans (specifically Antonio Ciccarelli and Gerolamo Berovardi) [Fig. 14.5]. ${ }^{25}$

There were many subsequent publications on this form of devotion, with some of them aimed explicitly at confraternities and including rules and indulgences. Others were intended to aid deeper consideration of the Rosary generally, with meditations, prayers, and images. Even a new order such as the Jesuits produced several works on the Rosary, starting with Gaspar Loarte's Instruttione et avertimenti, per meditare i misterii del rosario della Santissima Vergine Madre, first published in Rome in 1573. Later works included Luca Pinelli's Libretto d'imagini, e di brevi meditationi sopra i quindici misterii del rosario della sacratissima Vergine Maria per aiuto de' divoti della Madonna santissima, published in Naples in $1594 .{ }^{26}$ Although Loarte's earlier work was not illustrated, in Pinelli's book each mystery has its own illustration.

The illustrations in the Compendio dell'ordine e della regola del santissimo Rosario della gloriosa vergine by Niccolò Strata $(1588)^{27}$ are much more restrained. The author says that he modified a treatise by Mariano Lo Vecchio da Palermo, Compendio dellordine e della regola del SS rosario della Vergine (1579), to satisfy the requests of many 'Signori e Signore', and to add images. The combination of fifteen mysteries brings the material together into a united whole. While the events of the life of Christ are considered from a 'realistic' viewpoint, the manner in which the elements are brought together creates a more general perspective, intended to express the richness of the prayer [Fig. 14.6]. The illustration on the cover page reflects this, organizing as it does the fifteen mysteries into a sort of tree or garland, in which the fifteen icons are intertwined and circumscribe an image of the Virgin Mary holding the baby Jesus, both supporting a corona [Fig. 14.7]. The first set of meditations comes with images (one for each mystery), although the second set is not illustrated, while a number of further illustrations represent people reciting the Rosary.

In the following decades, the emblematic style led to the creation of more abstract and symbolic images, such as the Rosary emblem in Aresi's Imprese sacre. ${ }^{28}$ The Milanese Paolo Aresi published a sort of encyclopedia for preachers

\footnotetext{
25 It had been reprinted more than ten times before the end of the century.

26 It was later reprinted in his collected works, from 1600 on, as Meditationi vtilissime, sopra i quindeci misterij del rosario della sacratissima Vergine Maria.

27 Turin, Gio. Michele, e figli de' Cauallerij: 1588.

28 The multivolume work by Paolo Aresi Imprese sacre con triplicati discorsi illustrate \& arricchite a' predicatori, à gli studiosi della Scrittura Sacra was published across a span of years. The first introductory volume came out in Verona in 1615 , the second and third volumes in Milan in 1621, the fourth and fifth in Tortona in 1630, the sixth again in Tortona in $1634-5$, and the seventh in Tortona in 1640 .
} 


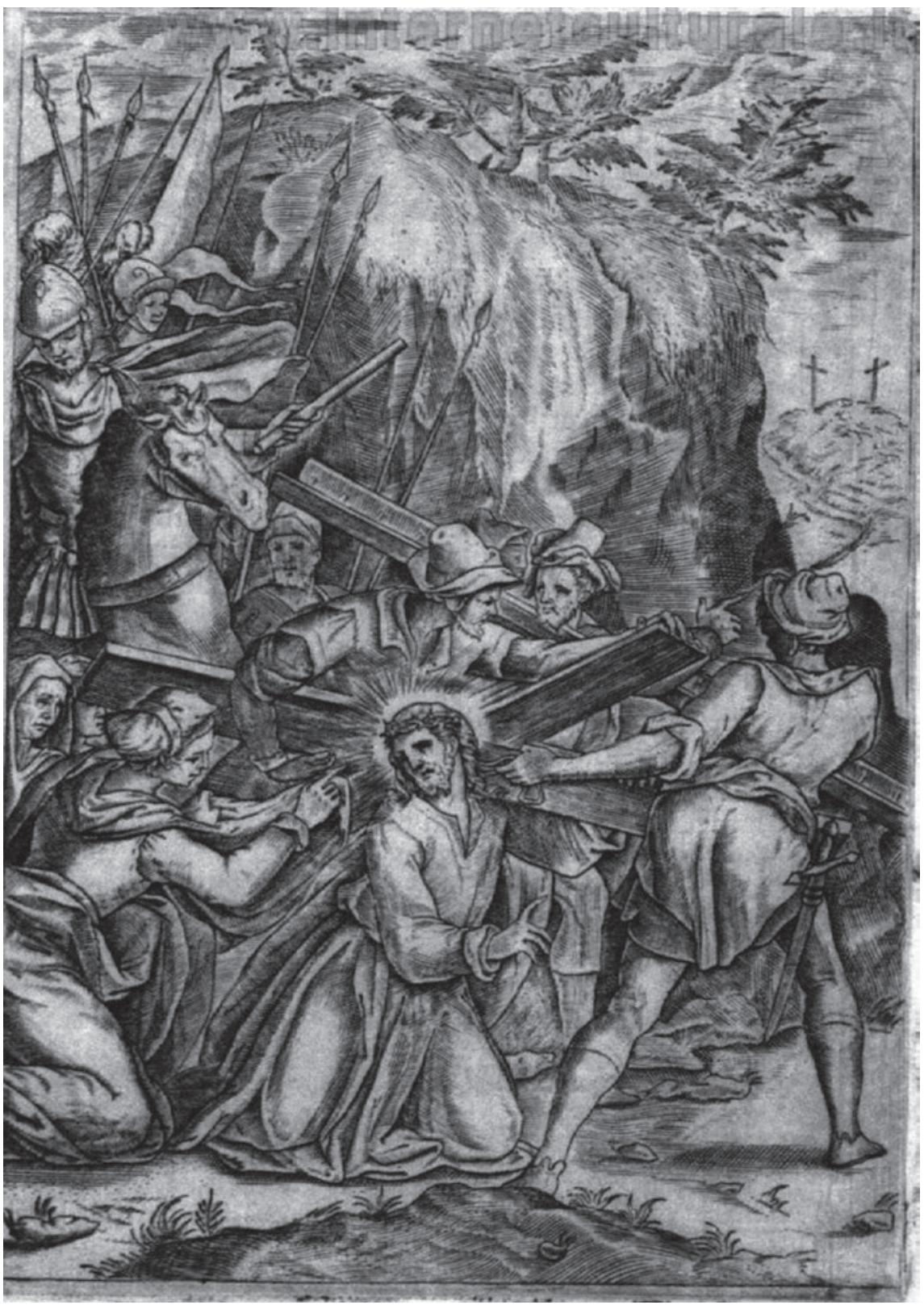

FIGURE 14.5 Luis de Granada, Rosario della sacratissima Vergine Maria, raccolto dall'opere del R.P.F. Luigi di Granata (Venice, Gioanne Varisco et Compagni: 1578) 136. By kind permission of the Biblioteca del Seminario del Polo Teologico Torinese, Turin 


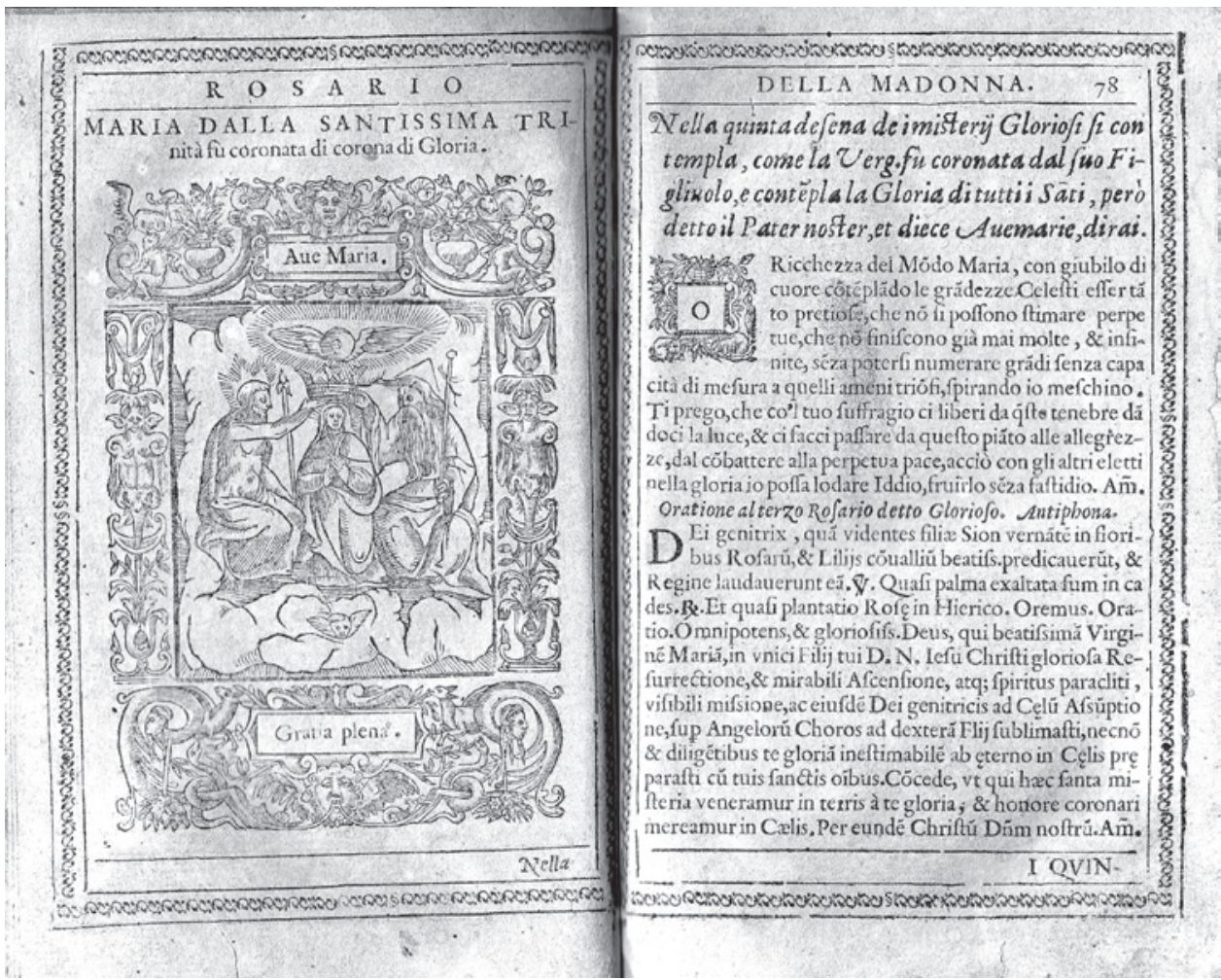

FIGURE 14.6 Strata Niccolò, Compendio dell'ordine e della regola del santissimo Rosario della gloriosa vergine (Turin, Gio. Michele, \& ff. de' Cauallerij: 1588) fols. $78 \mathrm{v}-79$ r. By kind permission of the Centro Teologico, Turin

organized around 200 emblems, each followed by three prose expositions giving topics for sermons. The illustrations of books 4-6 were carried out by the famous engraver Giovanni Paolo Bianchi of the Accademia Borromaica, and are masterpieces of the print age. The Rosary is presented as a garden of roses, a richly suggestive choice of imagery [Fig. 14.8]. The geometric composition conveys the idea of order and represents a calm world that seems to be part of a higher project or plan. The garden is more than simply plants and flowers: it is an organized space that implies the existence of a gardener who tends and arranges in a manner suggestive of a universal dispositio. It is not by chance that in the poem following the image Nature and Art are mentioned in verses that evoke Tasso's Gerusalemme liberata XVI, 10, for both compete in creating this perfect, enclosed space, which recalls the lost Garden of Eden. ${ }^{29}$ The images

29 The octave says: 'Di vaghe giovinette un bel drappello, / che di vari colori habbiano il manto, / sembra giardin, per cui ornar duello / con Natura fa l'Arte, e d'ogni canto / 


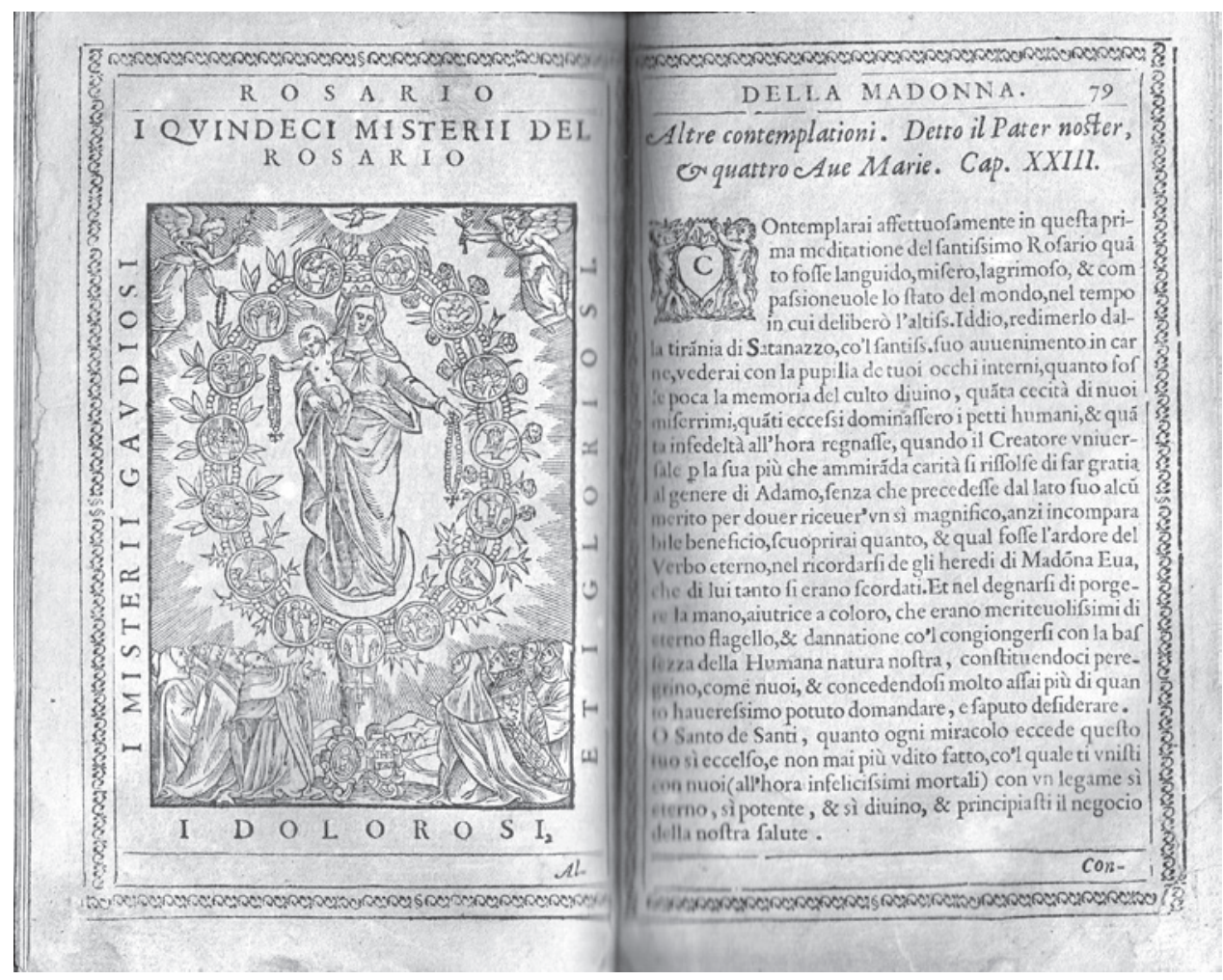

FIGURE 14.7 Strata Niccolò, Compendio dell'ordine e della regola del santissimo Rosario della gloriosa vergine (Turin, Gio. Michele, \& ff. de' Cauallerij: 1588) fols. 77v-78r. By kind permission of the Centro Teologico, Turin

portray the union of harmony and beauty. Even the frieze contributes to the message: it consists of two pots of roses, further reinforcing the significance of the rose and creating an exuberance of symbols, typical of Baroque art. The image also gives an idea of protection. The motto FORTITUDO ET DECOR comes from the Bible: Proverbs 31, 15. The work later explains that the Rosary is a hedge offering both beauty and protection and, as is stated in the last two verses, the Virgin is the guardian and defender of the Church.

In a later publication for preachers Tommaso Bracchi also presents the Rosary as an emblem signifying the salvation of the Church. The motto in L'impresa della catena del rosario di varie medaglie ornata da Maria (1643) and

coronato è di fior spinoso e bello, / che spira amor e in un minaccia il pianto. / Ma più vago è il giardin di Santa Chiesa, / e Rosario ha più forte a sua difesa' (Aresi, Imprese sacre VI 219). 


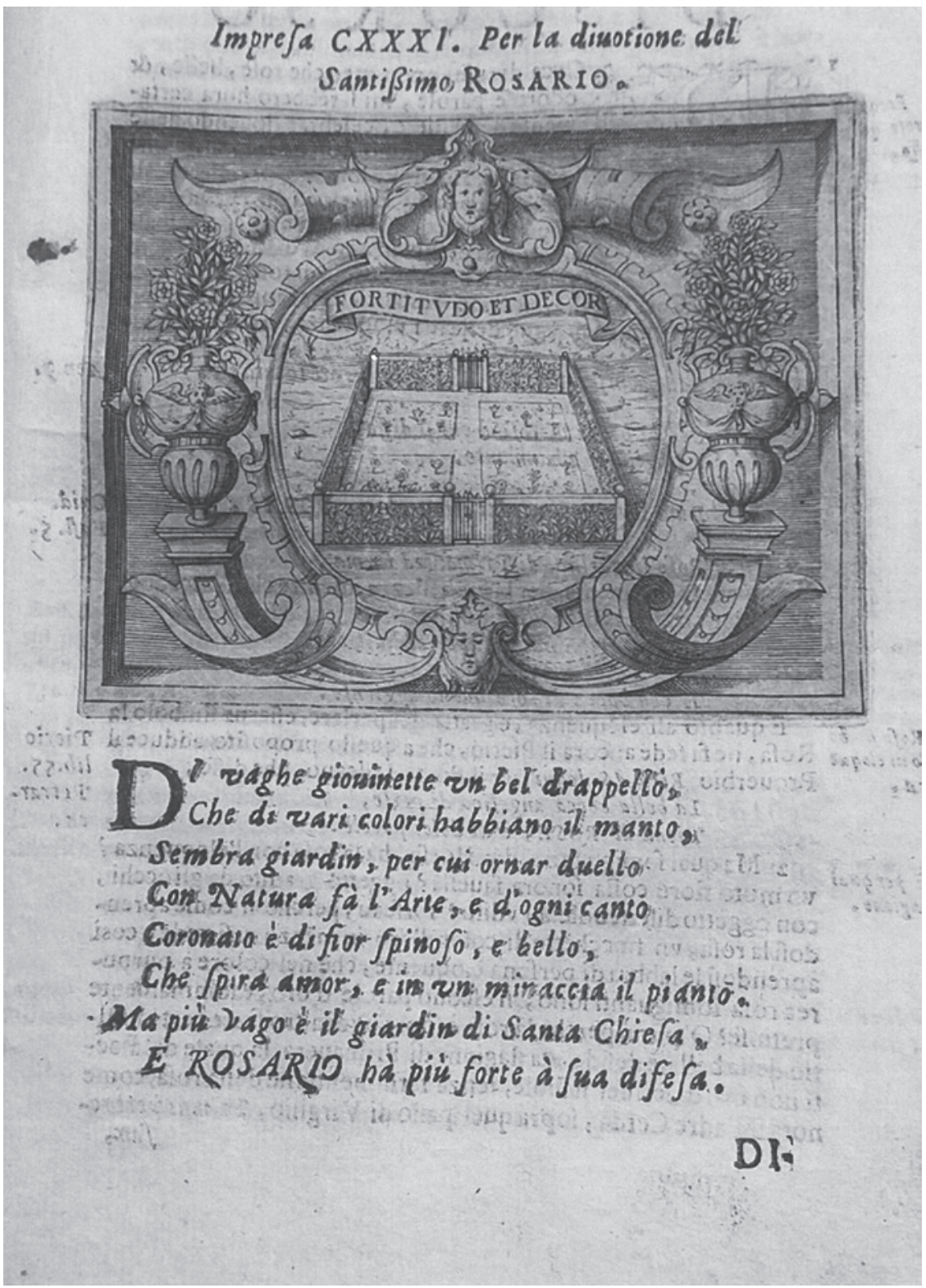

FIGURE 14.8 Aresi Paolo, Imprese sacre con triplicati discorsi illustrate \& arricchite a' predicatori, à gli studiosi della Scrittura Sacra VI (Tortona, Calenzano \& Viola: 1634-5) 219. By kind permission of the Biblioteca dei Cappuccini di Torino 
in the Le due imprese delle due corone de' rosarii (1633 and 1648), is IN HOC SALUS, and accompanies an image of a corona made of medals [Fig. 14.9]. The frontispiece is engraved by Bianchi, who re-used some of the figures created for Aresi's imprese. In fact, the images within the medals do not function as narratives, but are instead emblems which represent the fifteen mysteries symbolically. In his introduction the author justifies the use of symbolism, claiming it to be more suitable for divine matters, for they have to be apprehended by the senses but their deepest meaning can only be understood by the intellect. ${ }^{30}$

In addition to these texts about the Rosary, illustrated or not, with or without rules for confraternities and indulgences, we have to consider that preaching played a major role in the spread of this form of devotion among the laity. ${ }^{31}$ After the formal institution of the feast of the Virgin of the Rosary, sermons on the topic spread across Italy, sermons which clearly had the objective of inspiring this type of devotional practice among the audience or congregation.

Another genre that implicitly commented upon and encouraged the use of the Rosary was narrative poetry. A large amount of Italian verse on the topic was written in the sixteenth and seventeenth centuries. The narrative poem was an entertaining and fashionable genre, popularised by the success of chivalric poems, and was considered a useful means of providing behavioural examples in an engaging manner. Moreover, the Renaissance rediscovery of epic poetry based on Aristotelian rules and Homeric models, and the lesser or greater success of works by Trissino and Tasso, suggested that narrative could transmit the idea of a devotion which would be appropriate for use in the context of contemporary struggles against Protestants and Muslims. ${ }^{32}$

In fact the Rosary had early on been the object of attack by the Reformed Churches. Pietro Paolo Vergerio, the Istrian theologian and bishop who had converted to Lutheranism, published a virulent pamphlet in $155^{\circ}$ entitled $A$ quelli venerabili padri domenicani che difendono il rosario per cosa buona,

30 Bracchi Tommaso, Le due imprese delle due corone de' rosarii (Brescia, Carlo Biavino: 1648) n.n.

31 On sermons on the topic see Ardissino E., "Il rosario nella predicazione tra Cinque e Seicento", in Barile, Il Rosario tra devozione e riflessione 276-297.

32 On the significance and role of epic at the time, see Finucci V. (ed.), Renaissance Transactions. Ariosto and Tasso (Durham - London: 1999); Sberlati F., Il genere e la disputa. La poetica tra Ariosto e Tasso (Rome: 2001); Jossa S., La fondazione di un genere. Il poema eroico tra Ariosto e Tasso (Rome: 2002). 


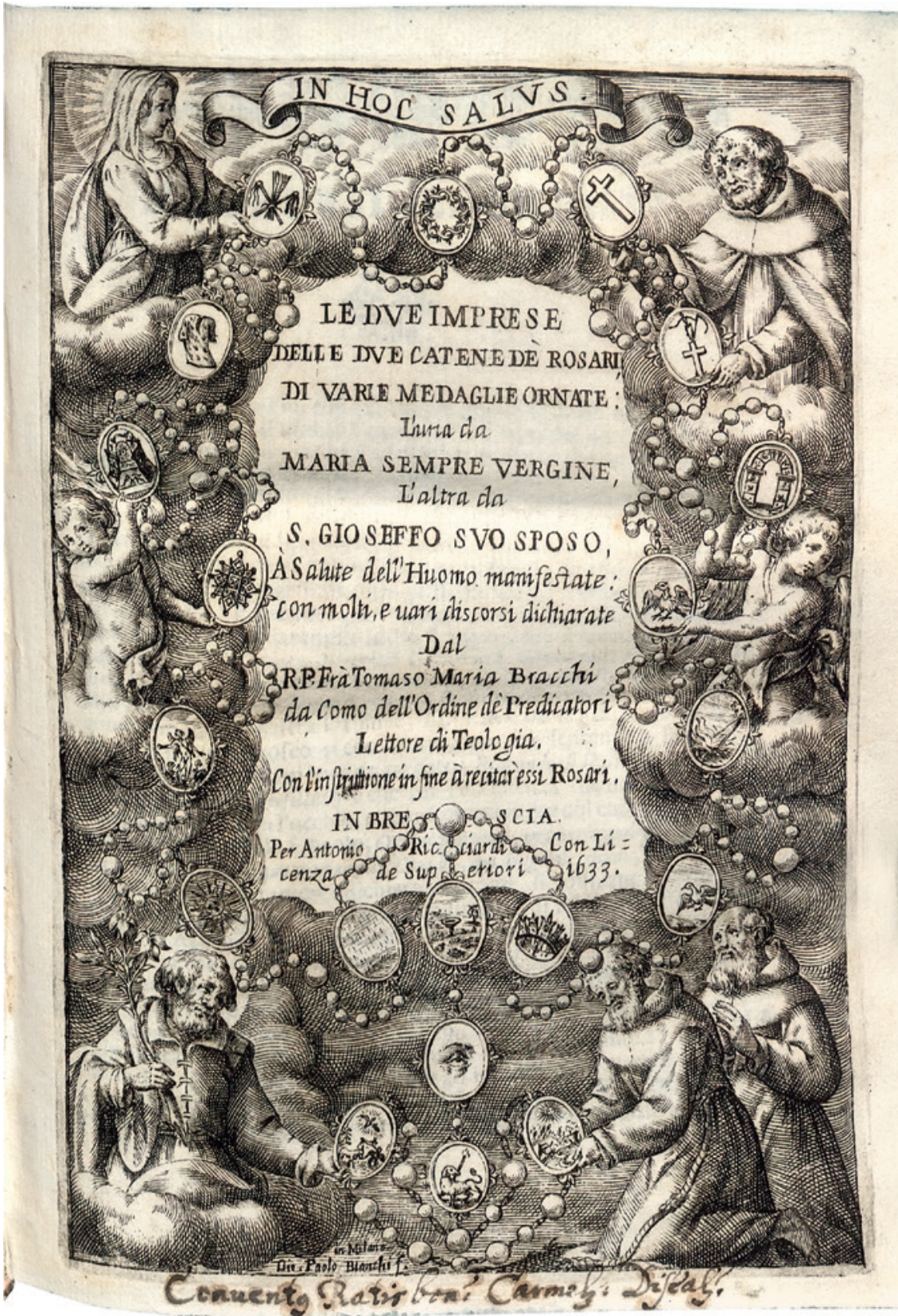

FIGURE 14.9 Bracchi T. Le due imprese delle due catene de' rosarii (Brescia: Antonio Ricciardi, 1633) frontispiece. By kind permission of the Staatliche Bibliothek Regensburg, 999/4Asc.162 
damning the devotion as an example of idolatrous Papist veneration. The Catholic Lorenzo Davidico responded in the same year by publishing a book entitled Il vittorioso trionfo di Maria Vergine contra i Luterani, while Gerolamo Muzio took up the issue in his letters (Lettere vergeriane, 1551 ). ${ }^{33}$ The Rosary therefore became known as a specifically Catholic devotion, and this perception was later supported by the official introduction of the feast celebrating the victory at Lepanto (Our Lady of the Rosary was even celebrated with the name Our Lady of the Victory). These political and epic connotations probably had an important influence on many of the long epic-like narrative poems or collections of short poems (mainly sonnets) in which poets celebrated and spread this Marian worship, combining devotion, ideological principles and identifying religious characteristics with modern narrative techniques. ${ }^{34}$

The features of the ritual had a decisive impact on these poems: indeed, the poetic narration was adapted to the needs of the prayer, with the poetic episodes constructed on the basis of each mystery. The events stay true to the Biblical narratives on which they are constructed, even as they are enriched with new imagery, including recent literary novelties such as the fight between demonic and angelic creatures, inspired by Tasso's invention in the fourth canto of his Gerusalemme liberata. ${ }^{35}$

The most successful of these poems was Capoleone Ghelfucci's Il rosario della Madonna, which was first published by Ghelfucci's heir in 1600 (the year of the poet's death) and had been reprinted twelve times by $1622 .{ }^{36}$ However, I will concentrate here on two earlier poems: Serafino Razzi's Rosario della gloriosissima vergine madre di Dio, Maria, avvocata di tutti i peccatori penitenti, published in 1583 , and Giulio Cesare Croce's Discorsi brevi, et facili sopra tutti i

33 On the Protestant refusal of the Rosary among other devotions see Caravale G., Forbidden Prayer. Church Censorship and Devotional Literature in Renaissance Italy, trans. P. Dawson (Farnham: 2011).

34 On the influence of modern post Reformation Catholicism on the spread of the Rosary see Mitchell N., The Mystery of the Rosary: Marian Devotion and the Reinvention of Catholicism (New York: 2009).

35 The battle between angels and demons portrayed by Tasso in the fourth canto of his poem soon became a model of the struggle between Evil and Good, and was therefore imitated in all poems concerned with Christian epic.

$3^{6}$ See Chiesa M., "Il poema sacro secentesco: uno sguardo ai frontespizi", in Arbizzoni G. Faini M. - Mattioli T. (eds.), Dopo Tasso. Percorsi del poema eroico. Atti del convegno internazionale di studi, Urbino 15-16 giugno 2004 (Rome-Padua: 2005) 285-309. For a more complete overview of poetry on the topic see Rosa M., "I trionfi del Rosario nella letteratura religiosa italiana della Controriforma", in Barile, Il rosario tra devozione e riflessione 298-313; for a poem not considered here see: Favaro M., "Un'architettura di versi, prose e immagini. Sul 'Mistico Tempio del Rosario' (1584) di Reginaldo Spadoni”, Aevum 90-3 (2016) 595-628. 
misterii del santiss. rosario, con altre compositioni spirituali composti ad instanza d'una reuer. monaca del Corpus Domini, published in 1598. These were more popular in nature than Ghelfucci's poem (which seems to be addressed to a literate audience capable of appreciating its creative use of characters, events and stylistic features), and without any pretensions of reaching the same social or literary heights, thus better reflecting the popular nature of the devotion itself. Moreover, they were produced in two cities, Florence and Bologna, which saw a large amount of confraternal activity and had an active religious culture beyond ecclesiastical institutions.

Serafino Razzi was a Florentine Dominican preacher, a biographer and follower of Savonarola and, above all, a musician, who revived laude poetry in the second half of the sixteenth century. ${ }^{37}$ His poem on the Rosary is dedicated by the author's brother to two Camaldolese nuns, Margherita Guadagni and Faustina Poggi, of the convent of San Giovanni Evangelista in Florence, and is framed as a response to a request from another nun, Cornelia Strozzi, of the convent of San Paolo in Orvieto. The dedication praises these three women as readers who greatly enjoy manuscripts as well as books, which suggests that the work is aimed at a female audience. It is not, however, necessarily addressed to nuns exclusively, because in his letter to the reader the author also indicates that his work is suitable for an audience that enjoys singing: it should please devout girls who respect God ('divote fanciulle e timorate di Dio'), as well as nuns and God's servants ('divote religiose e serve di Dio'). ${ }^{38}$ Girls and nuns can use his poetry as songs, because they reflect a pure soul and morally upright nature (the author probably intends his poetry to replace love songs). Razzi also underlines the importance of poetic Biblical translations, and enriches his text with Biblical references. His meditations are said to be drawn from Luis de Granada, and are developed through both poetry and prose, but without the use of images.

Each mystery is narrated in a short canto of octaves (from a minimum of twelve to a maximum of 32 ); the verse elaborates on biblical events with description and imaginative additions, which do not conflict with the evangelical narration but instead enrich it in order to suggest imagery to the reader. For example the first mystery, the Annunciation, starts with a domestic scene:

37 Razzi Serafino, Rosario della gloriosissima vergine madre di Dio (Florence, Sermartelli: 1583). On Razzi see Piéjus A., Musique et dévotion à Rome à la fin de la Renaissance. Les Laudes de l'Oratoire (Turnhout: 2013) 103-117.

38 Razzi, Rosario della gloriosissima vergine madre di Dio n.n. 


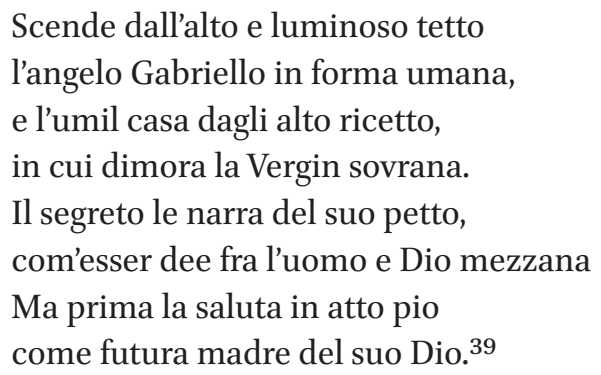

The way the moment is represented underlines its privacy: the story of salvation starts in a humble house, in the secrecy of Mary's heart. A dialogue between the angel and the Virgin Mary follows: it respects its source, the salutatio angelica of Luke 1, 28-33, even as it expands on it with additional comments and descriptions. Mary's humility is indicated by her blushing face ('mentre nel bel viso / della Vergin gentil parean due rose / le guance colte allora in paradiso'; while the cheeks of the beautiful face of the kind Virgin resembled two roses plucked in heaven). The second mystery, the visit of Mary to her cousin Elizabeth, is enriched with a description of the trip, including a night spent in a small lodging house to rest ('alcun alberghetto a riposarsi') and Mary's thanks to the host in the morning. The largest expansions concern events in the life of Christ related to the mysteries, but not included in them. Even though Razzi does not use the Apocrypha of the New Testament, he adds information, creates dialogues, and invents minor events which do not conflict with the Vulgate. The author also includes his observations in the form of prosopopoeia, speaking to people or even features of the surrounding area which witnessed the Gospel events, such as a speech directed at the donkey who brought Mary to Bethlehem, and one to the thorns of the passion ('crudeli acerbe e dispietate spine'). Sometimes the author engages the reader by calling her attention to particular events, or by urging her to devotion and reminding her of the principles of the faith. For example, at the first mystery of the sorrow the verse starts with an invitation to the soul to see Jesus in prayer at Gethsemane ('Anima mia, che fai, che pensi o miri? / Lievati presto e vanne ratta all'orto / Getsemani, là dove in gran sospiri / e lacrime vedrai Giesù assorto $\left.[\ldots]^{\prime}\right){ }^{40}$

39 Ibid., 1. 'The angel Gabriel in human form descends from the bright heights, and the humble house, in which the sovereign Virgin lives, offers him a honorable harbor. He tells her his heart's secret: that she has to mediate between God and human beings. But first he greets her as the mother of God with a pious greeting'.

$40 \quad$ Ibid., 58. 'My soul, what are you doing? What are you thinking? What are you looking at? Get up, quickly, and go swiftly to the Gethsemane garden where you will see Jesus lost in great sorrow and tears $[\ldots]$ '. 
Sometimes the context is explained with historical references, for example to the Roman census, or with Biblical references, such as the prefiguration of Christ in Abel, Moses, David or Isaac. Often the expansions consist of Mary's or Christ's thoughts, describing their feelings or introducing even more complex spiritual issues. Razzi's expansions give an interior dimension to the main figures, imagining their reactions to events, their knowledge of hidden meanings behind the surface story, and their explanations of them. For example, in the fourth mystery of joy Mary is represented before the Assumption recalling her life with Christ, a sort of synopsis of what has already been retold. Even theological problems are discussed in the form of a character's thoughts: for instance, in the mystery concerning the night in Gethsemane Christ explains to his three apostles (Peter, James, John) why he suffers, being God. Christ's words respond to a question shared by all believers, who have trouble comprehending Christ's Passion in the context of His divinity. With consideration of the nature of the human body, original sin, death, and the necessity of models for human suffering, Razzi clearly and simply explains the theological aspects of sorrow according to Catholic theology. In the mystery of the Crucifixion, the reader's soul is invited to go to Bethany to tell Mary about Christ's suffering and dying, with the suggested speech retelling the events. ${ }^{41}$

The verses are followed by a prose explanation in order to ensure clear comprehension, possibly because, as stated elsewhere, the work was written at a time when converting Biblical subjects into poetry was viewed with considerable suspicion. ${ }^{42}$ These parts are strictly faithful to their Biblical sources: only gospel references are explained, not the poetic or creative additions. Even if the explanations clearly refer to the Italian words used in the poetry, only those concepts derived from the source are clarified. The only exceptions are two explanations on stylistic choices, as I will discuss shortly. The prose explanations include references to a number of theological authorities, such as Augustine, Pseudo-Dionysius, Peter Damian, and Antonino Pierozzi, which are evidence of the author's religious culture. On one occasion he also adds instructions that clearly show how the Rosary is considered a domestic religious activity. In the fifth mystery of the joy, that on the recovery of the child Jesus in the temple of Jerusalem, Razzi adds a long exhortation to fathers, instructing them to keep

41 Ibid., 89: 'Intanto, anima mia, scostati un poco, / da sì fiero spettacolo, et in fretta / vanne piangendo di Betania al loco / a ritrovar Maria vergine eletta. / Inginocchiata a i piedi suoi con roco / parlar, racconta - ancor che intera / tra i sospir sie la voce - in quanti guai / veduto il suo figliuol dolcissimo hai'.

42 On Biblical censorship two books by G. Fragnito are essential: La Bibbia al rogo. La censura ecclesiastica e i volgarizzamenti della Scrittura (1471-1605) (Bologna:1997) and Proibito capire. La Chiesa e il volgare nella prima età moderna (Bologna: 2005). 
control of their children, above all during adolescence. He suggests praying with children, going to mass together, encouraging them in charitable acts, questioning them often on religious matters, supervising their reading material, and reading them saints' lives.

Razzi is a skilful poet who follows Petrarch's model. He even uses lines from Petrarch, as clearly seen in the commentary on the expression: 'la vedrai di sol vestita', used in relation to the Virgin Mary in the fiftieth glorious mystery. He writes in the prose commentary: 'Oltre che in questi versi si va imitando quel nostro nobilissimo poeta che disse: Vergine bella di sol vestita / coronate di stelle, etc. è da sapere che anco si allude alla bella e misteriosa vision di san Giovanni $[\ldots]^{\prime}{ }^{43}$ In the description of Paradise the verse 'vaghi augelletti, Progne e Filomena' (154), recalls Rerum vulgarium fragmenta 310. At the end of his work he adds the text of a song three octaves long (Stanze da cantarsi alla Madonna), which uses the incipit of RVF 366: 'Vergine bella che di sol vestita, / coronata di stelle, al sommo Sole / piacesti sì che per madre gradita / ti elesse ed esser volle egli tua prole' (164), and he goes on to construct a prayer that includes more words from Petrarch's canzone.

Tasso's influence is also evident, for example in the appeal to the soul in 'Anima, s'or non piangi, quando mai' (73): this recalls the end of the octave addressed to the crusaders' souls when they arrive at Jerusalem: 'Duro mio cor, ché non ti petri e frangi? / Pianger ben merti ognor, s'ora non piangi' (Gerusalemme liberata III, 8). Even more similar to these verses is 'ahi cuore, / ben sei più dur che adamantino sasso / se non ti muovi' (98). It is surprising that in the description of Heaven it is not Dante's, but Ariosto's influence, that is openly acknowledged: 'ci è piaciuto in questo luogo imitare alquanto i versi di quel gran poeta il quale parlando delle bellezze del paradiso terrestre con incredibile dolcezza disse: Zafir, rubini, oro, topazi e perle [...]', and he goes on to quote all octave 49 of canto 34 of Orlando furioso. ${ }^{44}$

Razzi uses common rhetorical devices, such as metaphors, lengthy similes and puns, and even at one point an invocation to the Muses. ${ }^{45}$ Sometimes

43 Razzi, Rosario della gloriosissima vergine madre di Dio 163 'Besides the fact that these verses imitate our very noble poet who said: Vergine bella di sol vestita / coronate di stelle, etc., it should be known that there is an implicit reference to Saint John's beautiful and mysterious vision'. In the following quotations the page reference is given in parentheses.

44 Ibid., 161. 'It pleased us here to imitate the verses of that great poet who, telling of the beauties of the earthly paradise, said with incredible sweetness Zafir, rubini, oro, topazi e perle $[\ldots]$ '.

45 One of the longest similes compares the growing sorrow of the passion to a swollen river: 'Qual rapido torrente, che da molte / acque ingrossato cresce a poco a poco, / e quindi poi spargendo le già accolte / innonda d'ogni intorno ciascun loco, / così serpendo con giri e rivolte / danneggia più che non fa in selva foco / talor contempla, o anima fervente, 
the verse includes quotations from other poetry, for example in the mystery of Pentecost one octave is a translation of part of the sequence Veni Sancte Spiritus in Italian (136) and often Razzi's verses echo biblical ones: 'Chi di colomba mi darà le penne' ( 152 - Ps 54,7 but also RVF 48 ) or 'Stupite cieli e piangete elementi' (97-Jer 2, 13).

In a later sermon dedicated to this form of worship, Razzi says that the Rosary enlightens the intellect and inflames the emotions, and argues that it should be widely used, highlighting the many correspondences between the numerology of the Rosary and that of the Bible, and suggesting that the Rosary can be considered spiritual medicine in the way that the rose plant offers medicine for the body. ${ }^{46}$

The second work, which is also dedicated to a nun, is by Giulio Cesare Croce, who is well known for his stories of Bertoldo and Bertoldino but underestimated as a religious writer. ${ }^{47} \mathrm{He}$ was a blacksmith working in San Giovanni in Persiceto, a village near Bologna, where he used to travel to sell his poetry and stories. His work on the Rosary begins with a brief prohemium on contemplation, a poem (a sonetto caudato: Salutatione alla Vergine) of 17 anaphorical verses, all starting with $A v e$, and an octave which is a general consideration of the Rosary:

Le contemplazioni alte e devote qui si descrivon del rosario santo acciò chi legge possa in brevi note i gran misteri meditare alquanto, ché in questo bel giardin coglier si puote la rosa, il giglio, il croco e l'amaranto, e ogn'alma fida che ne coglie e prende felice e lieta sopra il cielo ascende. ${ }^{48}$

della passione il rapido torrente". Ibid. 68. For a pun, see for example the following line referring to the soldier who kills Jesus: 'avendo alla pietà chiuse le porte / alla stessa pietà vanno a dar morte' (92). For the invocation to the Muse Talia see 140: 'Alta materia e difficil soggetto / ci si porge or seguendo il cantar nostro, / che lingua più faconda e miglior petto, / penna più atta e più purgato inchiostro / ricercherebbe e non scrittor sì inetto / come son io fra quanti abitan chiostro, imperoché cantar deve or Talia, / come fu assunta in ciel la Vergin pia'.

46 Razzi Serafino, Sermoni predicabili (Florence, Sermartelli: 1590) 89-101.

47 On Croce see Camporesi P., Il palazzo e il cantimbanco. Giulio Cesare Croce (Milan: 1994); on his quaresimale, see Ussia S., L'aspro sentiero. Poesia quaresimale di Pietro Cresci e Giulio Cesare Croce (Vercelli: 2003).

48 Croce Giulio Cesare, Discorsi breui, et facili sopra tutti i misterii del santiss. rosario (Bologna, Heredi di Gio. Rossi: 1598) 89. 'Devout and lofty contemplations of the holy 
Each mystery is presented with an image facing the verse. The reader is then instructed to recite the Pater noster and ten Ave Marias, each preceded by a terzina. Every repetitive prayer is therefore associated with a brief poetic meditation, which underlines the role of silent prayer. The incipit is as follows:

\author{
PATER NOSTER \\ Dal re del cielo i patriarchi santi \\ braman ch'ei mandi in terra il Salvatore, \\ qual ponga fine a i lor amari pianti. \\ AvE MARIA \\ Sotto varie figure a noi si mostra, \\ che Maria sola portarà quel frutto, \\ che sia cagion de la salute nostra. \\ Ave MARIA. ${ }^{49}$
}

Together, the terzine reconstruct the history of salvation, with special attention paid to the role of the Virgin Mary, whose life since childhood is narrated. The narration expands on its source, the Gospels, with creative insights. For example in the second mystery of joy, Mary's visit to Elizabeth, the poet adds depth to the relationship between the two cousins with domestic observations: 'Nato Giovanni, ne le sante braccia / Maria l'accoglie e con somma allegrezza / a se lo stringe e caramente il baccia', and later, when Jesus' birth is being considered, a simple reference to the baby's needs gives an idea of the poet's unusual sensitivity: 'Miracolosamente il latte impetra / Maria, e I picciol figlio ciba e pasce'.50 In the fourth mystery the holy family's practical life is again considered with a brief mention to their everyday reality: 'Per dare al picciol figlio gli alimenti / s'affaticano i santi genitori: / o fatiche soavi, o dolci stenti. ${ }^{51}$ Like Razzi, Croce presents various events of Christ's life, even those not considered as mysteries. For example, in the last mystery of joy each terzina recounts an episode: the forty days in the desert, the miracle at Cana, the choosing of the apostles,

Rosary are described here, so that the reader can long meditate on the great mysteries in short passages. In this garden one can pick the rose, the lily, the crocus and the amaranth, and every faithful soul who picks and takes it will ascend to heaven happy and blessed'.

49 Ibid., 101. 'The holy patriarchs ask the King of Heaven to send the Saviour to earth, so that he can end their bitter weepings. Ave Maria. By various means we see, that only Mary can carry that fruit, which will be our safety. Ave Maria'.

Quotations are respectively: ibid., 12 'Once John was born, Mary takes him in her holy arms, and with great joy clasps him to herself and kisses him affectionately'; 15 'Mary begs to have milk miraculously, and she feeds and nourishes her little son'.

$5^{1} \quad$ Ibid., 18. 'The holy parents make every effort to feed their little child. Oh, sweet struggle, oh, sweet effort'. 
the Transfiguration, the washing of Christ's feet by the penitent woman, miraculous healings. Sometimes (as for the first mystery of the sorrow) the narration of the many events of Christ's life takes such prominence that the event of the mystery itself is almost forgotten. The terzine even include the events of the Acts of the Apostles, as they appear in the third mystery of glory, where the miracles of Peter, his imprisonment, and his release by the angel are recounted.

From time to time (approximately every ten terzine) the devout reader's attention is demanded in the second person: 'Contempla il lor amor, anima pia' (13); 'Contempla, anima mia, quanta allegrezza' (15); 'Piangi, anima divota, l'aspre e dure / percosse' (29); 'Anima mia, perché cotante pene / ha da partire il re de gli alti scanni?' (35). ${ }^{52}$ The terzine alone provide the commentary on each mystery and there are no prose meditations, only a prose prayer after each group of mysteries. Three compositions follow: a sonnet on the passion, a canto of 23 octaves on the contemplation of Christ's sorrows, and a capitolo of 19 terzine on the cross.

Croce follows the same models as Razzi, but less strictly. Petrarch is clearly recalled in 'per la pietà del suo Fattore i rai' (39, RVF 3), and he cites the same Tasso verses recalled by Razzi in 'Se mai piangesti, o dura anima mia, / or piangi' (32). We find even an echo of Dante (Purgatorio 30, 137) in 'perdute genti' (20). Croce is certainly a less ambitious poet than Razzi, but his work enjoyed modest success, being published again in 1612 and around 1620 .

It is clear from the prayers situated at the end of each group of mysteries that the devout reader is supposed to be a woman, specifically the dedicatee. The interest of a female audience in this kind of literature is confirmed by a poem by a woman, Francesca Turini Bufalini, Rime spirituali sopra i misterii del santissimo rosario, printed in 1595 (reprinted in 1628). ${ }^{53}$ It is dedicated to the Pope in a letter in which the poet affirms the dignity of poetry, frequently recalling her own female sphere (such as her clothes and domestic duties), which she then situates within a martial context by mentioning her father, who fought in the French religious wars, and her husband, also involved in naval warfare in the Mediterranean. The work is divided into three parts, one for each kind of mystery, gaudiosi, dolorosi, gloriosi, with each group composed

$5^{2}$ Contemplate their love, my soul; Contemplate, my soul, such happiness; Weep, devout soul, for the harsh and brutal blows; My soul, why must the king of the highest ranks suffer so many torments?

53 There is a recent edition edited by Bà Paolo and published in Letteratura italiana antica 9 (2010) 145-223. On the author see "Atti della giornata di studio su Francesca Turini Bufalini", in Letteratura italiana antica 16 (2015) 579-617, with essays by P. Bà, N. Costa-Zalessow N., and G. Rossi. 
of fifty meditative sonnets (addressed to the soul who is praying, with an invitation to contemplation), and each part introduced by a madrigal.

Another interesting example of the popularity of Rosary poetry is the Nouo rosario della gloriosissima Vergine Maria, a collection of poems by Gaspare Ancarano, in which the poet not only describes the mysteries in Italian, but also translates the Pater noster into Italian fifteen times, once for each mystery, combining classical and biblical mythology. ${ }^{54}$ The translation shows that this form of devotion was considered suitable for the laity and those unfamiliar with Latin, and also that it was thought capable of providing more profound insights into the basic tenets of the Catholic faith.

The use of the vernacular was essential for the spread of the Rosary, because its narratives make up a sort of first catechism for teaching, which began in childhood. The familial nature of this form of worship for Catholics in the early modern age is even shown by the works of St. Teresa of Avila, who recalls in her autobiography that her mother taught her to recite the Rosary when she was still a child..$^{55}$

The many publications on this form of devotion in early modern Italy discussed here constitute an archive of evidence for the diffusion of the Rosary. Its spread was obviously aided by publications on the indulgences granted by popes, and on the rules of confraternities. The devotion was of course also supported by artistic production, painting and the building of chapels, that is, spaces created and decorated particularly for one purpose, which also had a collective function. However, it is the literary and iconographic production which best helps us to understand why the Rosary became a practice so deeply embedded in all levels of Italian society, and why the devotion, which combines meditation with narratives, mainly based on the lives of Mary and Christ, was used to sanctify and characterise the most meaningful moments of private and domestic life.

\section{Selective Bibliography}

\section{Primary Sources}

Alberto da Castello, Rosario della gloriosa Vergine Maria (Venice, Marchio Sessa et Piero di Rauani: 1522).

54 Ancarano Gaspare, Novo rosario della gloriosa Vergine Maria con quindeci sonetti in esposition delli quindeci Pater nostri (Venice, Giunti: 1588).

55 Teresa of Avila, The book of Her Life, in Teresa of Avila, Collected works, trans. O. Rodriguez (Washington DC: 1987) I, 55 . 
Ancarano Gaspare, Novo rosario della gloriosa Vergine Maria con quindeci sonetti in esposition delli quindeci Pater (Venezia, Giunti: 1588).

Aresi Paolo, Imprese sacre con triplicati discorsi illustrate \& arricchite a' predicatori, à gli studiosi della Scrittura Sacra VI (Tortona, Calenzano \& Viola: 1634-5).

Bracchi Tommaso, Le due imprese delle due corone de' rosarii (Brescia, Carlo Biavino: 1643).

Croce Giulio Cesare, Discorsi breui, et facili sopra tutti i misterii del santiss. rosario (Bologna, Heredi di Gio. Rossi: 1598).

Luis de Granada, Rosario della sacratissima Vergine Maria, raccolto dall'opere del RPF Luigi di Granata (Venice, Gioanne Varisco et Compagni: 1578).

Loarte Gaspar, Instruttione et avertimenti, per meditare $i$ misterii del rosario della Santissima Vergine Madre (Rome, Iustina de Rossi: 1573).

Pinelli Luca, Libretto d'imagini, e di brevi meditationi sopra i quindici misterii del rosario della sacratissima Vergine Maria per aiuto de' divoti della Madonna santissima (Naples, G. Carlino \& A. Pace: 1594).

Strata Niccolò, Compendio dell'ordine e della regola del santissimo Rosario della gloriosa vergine (Turin, Gio. Michele, \& ff. de'Cauallerij: 1588).

Razzi Serafino, Rosario della gloriosissima vergine madre di Dio (Florence, Bartolomeo Sermartelli: 1583$)$.

Turini Bufalini Francesca, Rime spirituali sopra i misterii del santissimo rosario, in Bà P. (ed) Letteratura italiana antica, 9 (2010) 145-223.

\section{Secondary Sources}

Arancibia P., "La funzione delle immagini nel Rosario della Sacratisisma Vergine Maria Madre di Dio nostra signora", in Ardissino E. - Selmi, E. (eds.), Visibile teologia. Il libro sacro figurato tra Cinque e Seicento (Rome: 2012) 179-190.

Barile R., Il rosario, salterio della Vergine (Bologna: 1990).

Barile R. (ed.), Il rosario tra devizione e riflessione, Sacra Doctrina 54, 4 (2009).

Caravale G., Forbidden Prayer. Church Censorship and Devotional Literature in Renaissance Italy, trans. P. Dawson (Farnham: 2011).

Chiesa M., Il poema sacro secentesco: uno sguardo ai frontespizi, in Arbizzoni G. Faini M. - Mattioli T. (eds.), Dopo Tasso. Percorsi del poema eroico. Atti del convegno interanazionale di studi, Urbino 15-16 giugno 2004 (Padua: 2005) 285-309.

Duval A., "Rosaire", in De Guibert J. - Viller M. - Cavallera F. (eds.), Dictionnaire de spiritualité (Paris: 1988) 937-80.

Fattori D., "Frate Alberto da Castello, un domenticano in tipografia", Bibliofilia 109 (2009) 144-167.

Finucci V. (ed.), Renaissance Transactions. Ariosto and Tasso (Durham - London: 1999).

Fragnito G., La Bibbia al rogo. La censura ecclesiastica e i volgarizzamenti della Scrittura (1471-1605) (Bologna: 1997). 
Fragnito G., Proibito capire. La Chiesa e il volgare nella prima età moderna (Bologna: 2005).

Gatti Perer M.L., "Per la definizione dell'iconografia della Vergine del Rosario", in Zardin D. (ed.), Carlo Borromeo e l'opera della 'Grande Riforma'. Cultura, religione, arte del governo nella Milano del pieno Cinquecento (Milan: 1997) 185-208.

Jossa S., La fondazione di un genere. Il poema eroico tra Ariosto e Tasso (Rome: 2002).

Meersseman G.G., Ordo fraternitatis, confraternite e pietà dei laici nel Medioevo (Rome: 1977) 1044-1070.

Mitchell N., The Mystery of the Rosary: Marian Devotion and the Reinvention of Catholicism (New York: 2009).

Quétif Jacques - Echard Jacques, Scriptores Ordinis Praedicatorum (Paris: 1719-1721) I, 849-852.

Rosa M., Religione e società nel Mezzogiorno tra Cinque e Seicento (Bari: 1976) 217-143.

Sberlati F., Il genere e la disputa. La poetica tra Ariosto e Tasso (Rome: 2001).

Winston-Allen A., Stories of the Rose. The Making of the Rosary in the Middle Age (University Park PA: 1997). 